\title{
UJI FITOKIMIA DAN AKTIVITAS ANTIOKSIDAN CENDOL YANG DIFORMULASI DARI RUMPUT LAUT (Kappaphycus alvarezii) DAN TEPUNG SAGU (Metroxylon sagus Rottb.)
}

\author{
Arum Ayu Gustiara Absyah Saleh *, Asnani, Suwarjoyowirayatno \\ Jurusan Teknologi Hasil Perikanan Fakultas Perikanan dan Ilmu Kelautan Universitas Halu Oleo, \\ Jalan H.E.A Mokodompit Kampus Bumi Tridharma Anduonohu, Kendari 93232 Sulawesi Tenggara \\ Telepon +6285242454613 \\ *Korespondensi: Fatihsundalanyaarum@ gmail.com \\ Diterima: 6 Maret 2019/Disetujui: 1 april 2019
}

Cara sitasi: Saleh AAGA, Asnani, Suwarjoyowirayatno. 2019. Uji fitokimia dan aktivitas antioksidan cendol yang diformulasi dari rumput laut (Kappaphycus alvarezii) dan tepung sagu (Metroxylon sagus Rottb.). Jurnal Fish Protech. 2(1):38-45.

\begin{abstract}
Abstrak
Tujuan penelitian adalah untuk mengetahui kandungan fitokimia dan aktivitas antioksidan pada bulir cendol rumput laut Kappahycus alvarezii dengan penambahan tepung sagu yang diekstraksi dengan pelarut methanol. Ekstrak diperoleh dengan cara maserassi terhadap bulir cendol rumput laut dan tepung sagu. Uji fitokimia dilakukan untuk mengetahui keberadaan senyawa alkaloid, flavonoid, saponin, streroid dan triterpenoid. Aktivitas antioksidan bulir cendol Kappaphycus alvarezii diuji dengan metode DPPH ( $1-1$ difenil -2 pikrilhidrazil). Penelitian ini menggunakan Rancangan Acak Lengkap (RAL) yang terdiri dari tiga perlakuan yaitu perlakuan R1S1 (RL : 10\% TS : 90\%), R2S2 (RL : 20\%: TS : 80\%), R3S3 (RL $30 \%$ TS : 70\%) dan ulangan sebanyak tiga kali. Data hasil pengamatan dianalisa menggunakan ANOVA (Analysis of Variance) pada taraf 95\%, apabila terdapat beda nyata $(\mathrm{P}>0,05)$ maka dilakukan uji lanjut dengan uji DMRT (Duncan Multiple Range Test) pada taraf nyata 95\%. Hasil penelitian mempelihatkan terdeteksi senyawa alkaloid, flavonoid, streroid dan triterpenoid sedangkan pada senyawa saponin tidak terdekteksi pada ekstrak metanol cendol Kappaphycus Alvarezii. Uji aktivitas antioksidan dengan metode DPPH menunjukan nilai $\mathrm{IC}_{50}$ terendah terdapat pada perlakuan R1S1 dengan jumlah $\mathrm{IC}_{50} 652 \mathrm{ppm}$. Hal ini menunjukan bahwa adanya aktivitas antioksidan yang sangat lemah dari cendol Kappaphycus alvarezii yang diekstraksi.
\end{abstract}

Kata Kunci : Aktivitas antioksidan, cendol, Kappaphycus alvarezii, Metroxylon sagus Rottb, fitokimia 


\title{
PHYTOCHEMICAL AND ANTIOXIDANT TEST OF CENDOL FORMULATED FROM SEAWEED (Kappaphycus alvarezii) AND SAGO FLOUR (Metroxylon sagus Rottb.)
}

\begin{abstract}
The aims of this study was to determine the phytochemical content and antioxidant on cendol seaweed (Kappaphycus alvarezii) with additions of sago flour (Metroxylon sagus Rottb.) extracted with methanol. Phytochemical tests were performed to determine the presence of alkaloids, flavonoids, saponins, triterpenoids and steroids. Antioxidant activity of seaweed cendol. Kaphaphycus alvarezii was tested by DPPH method (1-1- diphenyl-2-picrylhydrazl). This study used a Completely Randomized Design (CRD) which consists of three treatments R1S1( RL 10\%: TS 90\%), R2S2 (RL 20\% : TS 80\%), R3S3 (RL 30\%: TS : 70\%) and three times replication. Observation data were analyzed using ANOVA (Analysis of Variance) at the level of 95\%, if there were significant differences ( $P>0.05)$ then further testing was carried out with DMRT (Duncan Multiple Range Test) at 95\% significance level. Phytochemical test showed there was compounds detected with alkaloids, flavonoids, triterpenoids and steroids. While the saponins compounds was not detected in methanol extract of Kappahycus alvarezi. The antioxidant activity by DPPH method showed that the high $\mathrm{IC}_{50}$ values is $652 \mathrm{ppm}$. That was indicated seaweed cendol from kappaphycus alvarezii has lower antioxidant activity.
\end{abstract}

Key words: Antioxidant activity, cendol, Kappaphycus alvarezii,Metroxylon sagus Rottb., phytochemical,

\section{PENDAHULUAN}

Rumput laut merupakan komoditas andalan nasional disektor perikanan. Hal ini dijelaskan melalui kebijakan yang menempatkan rumput laut sebagai target komoditas utama yang diharapakan mendongkrak perolehan devisa Negara. Hal tersebut didasarkan pada beberapa kelebihan rumput laut seperti pembudidayaan rumput laut relatif singkat yaitu selama 45 hari, produktifitas tinggi, kandungan gula monomer maupun polimer sehingga baik sebagai sumber pangan. Produksi rumput laut Indonesia mencapai 4.305.027 ton (KKP, 2011).

Beberapa jenis rumput laut merupakan sumber potensial pangan fungsional yang dapat dimanfaatkan untuk kesehatan karena mengandung senyawa kimia yang mempunyai aktivitas biologis (zat boaktif). Senyawa aktif biologis itu merupakan metabolit sekunder yang meliputi alkaloid, flavonoid, terpenoid, tannin, dan saponin. Menurut Kardono (2004) terdapat sekitar 2500 jenis senyawa bioaktif dari laut yang telah berhasil diisolasi dan diidentifikasi, dan 93\% di antaranya diperoleh dari rumput laut. Kandungan antioksidan pada rumput laut terutama berupa senyawa antioksidatif

(Siriwardhana et al., 2003).

Rumput laut banyak diolah dalam bentuk kering setelah melalui proses penjemuran atau diolah menjadi makanan siap dikonsumsi seperti dodol, manisan dan minuman. Saat ini kebanyakan makanan siap 
konsumsi yang dijual masyarakat adalah minuman sari buah, tetapi untuk minuman dari rumput laut jarang ditemui dilingkungan masyarakat (Nursanto, 2004). Berdasarkan kandungan gizi rumput laut yang cukup banyak, pemanfaatan rumput laut dalam bidang pengolahan cukup melimpah, salah satunya pada produk cendol. Cendol umumnya dibuat dari tepung beras, tepung ketela, tepung tapioca, tepung hunkwe, atau jenis-jenis tepung lainya. Cendol dibuat dengan cara mencampurkan beberapa jenis tepung (Anggraeni, 2002).

Menurut Arabei (2000), rumput

laut dapat bermanfaat untuk memperbaiki proses pencernaan dan penyerapan sari makanan serta memperbaiki peristaltic cusus. Rumput laut juga merupakan sumber vitamin terutama vitamin B,Cdan E. Penambahan rumput laut pada pembuatan cendol dapat meningkatkan kandungan antioksidan dan serat.

Komoditas yang dapat dimanfaatkan selain rumput laut dalam proses pengolahan makanan yaitu sagu. Sagu merupakan komoditas andalan yang dapat digunakan sebagai sumber karbohidrat potensial, terutama untuk kawasan Timur Indonesia. Sagu dimanfaatkan sebagai bahan pangan alternatif, dalam bentuk pangan pokok seperti sinonggi, kapurung atau papeda (Muhidin et al., 2012)

Pati sagu memegang peranan penting dalam industi pengolahan pangan secara luas juga dipergunakan dalam industri seperti permen, glukosa, dekstrosa, sirup fruktosa, dan lain-lain (Koswara, 2009). Sagu dan rumput laut dapat dimanfaatkan dalam bentuk olahan pangan untuk meningkatkan nilai gizi produk. Salah satunya adalah produk cendol yang merupakan makanan tradisional Indonesia. Berdasarkan latar belakang diatas maka dilakukan penelitian tentang Uji Fitokimia dan aktivitas Antioksidan Cendol yang diformulasi dari Rumput Laut (Kappaphycus Alvarezii) dan Tepung Sagu (Metroxylon Sagus Rottb.

\section{BAHAN DAN METODE}

\section{Bahan dan Alat}

Bahan yang akan digunakan dalam penelitian ini adalah rumput laut (K. alvarezii) yang diperoleh dari Desa Tanjung Tiram, Konawe Selatan. Bahan utama adalah bubur rumput laut (K. alvarezii) sedangkan bahan baku cendol adalah tepung sagu (Metroxylon sagus Rottb.), air mineral, air es dan pewarna makanan aroma pandan.

Peralatan yang digunakan dalam penelitian ini ada 2 macam yaitu alat untuk pengolahan dan alat untuk analisis. Alat pengolahan meliputi:baskom, pisau, blender, cetakan cendol, ayakan stainless steel akebonno diameter $25 \mathrm{~cm}$, panci, dan kompor. Alat untuk analisis fitokimia dan aktivitas antioksidan meliputi: Evaporator merek stuart RE 3022, neraca analitik merek boeco dan cheetah, incubator, spektofotometer UV-Vis merek hitachi U-2900, kertas saring Whatman no. 42, alumunium foil merek bagus (kichen care) dan alat- alat gelas (gelas ukur, pipet volume, gelas kimia, alat gelas lain) merek pirex, ducan dan iwaki glass.

\section{Pembuatan cendol rumput laut modifikasi metode Ari (2008)}

Pembuatan tepung sagu meliputi, sagu segar terlebih dahulu 
direndamdalam air dan kemudian ditiriskan untuk memisahkan kotoran, kemudian direndam \pm 24 jam, dan setiap 12 jam air harus diganti, setelah itu sagu dijemur di bawah sinar matahari \pm 2 hari/sampai kering dan kemudian diayak dengan menggunakan pengayak 80 mesh untuk mendapatkan tepung sagu (Mulyo, 2016), Sedangkan pada pembuatan bubur rumput laut, rumput laut yang digunakan dalam pembuatan cendol yaitu rumput laut K.alvarezii dicuci dengan air mengalir untuk menghilangkan kotoran yang tertinggal pada rumput laut lalu direndam selama 24 jam dengan air cucian beras.Setelah proses pengilingan dillakukan, bubur rumput laut lalu disimpan diwadah plastik dan ditutupi alumunium foil untuk mengurangi terpapar sinar matahari langsung atau cahaya lampu. Pembuatan adonan adalah pencampuran semua bahan hingga homogen tepung sagu, bubur rumput laut dan air dicampur dalam pencampuran ini dilakukan selama \pm 5 menit hingga terbentuk adonan yang homogen dalam keadaan semi basah.

Setelah proses pembuatan adonan selesai, adonan dicetak dengan menggunakan alat khusus pembuat cendol berbahan stainless, adonan dituang dalam cetakan cendol. Tekan-tekan lalu dijatuhkan dalam air mendidih selama \pm 2 menit. Penirisan dilakukan setelah cendol matang lalu dimasukan ke dalam air matang yang berisikan es batu.

\section{Uji Fitokimia}

Analisis fitokimia dilakukan
antara lain flavonoid, alkaloid,
saponin, triterpenoid/steroid.

Analisis fitokimia dilakukan saponin, triterpenoid/ steroid.

\section{Uji Aktivias Antioksidan}

Analisis aktivitas antioksidan mengacu pada Salazar-Aranda et al., (2009) dengan metode DPPH.

\section{Rancangan Penelitian}

Penelitian ini menggunakan Rancangan Acak Lengkap (RAL) yang terdiri dari tiga perlakuan yaitu R1S1 (R110\% : S1 90\%), R2S2 (R220\% : S2 80\%)dan R3S3(R330\%: S3 70\%), Masing-masing perlakuan dilakukan tiga kali ulangan, sehingga diperoleh jumlah satuan percobaan sebanyak 9 unit.

\section{Analisis Data}

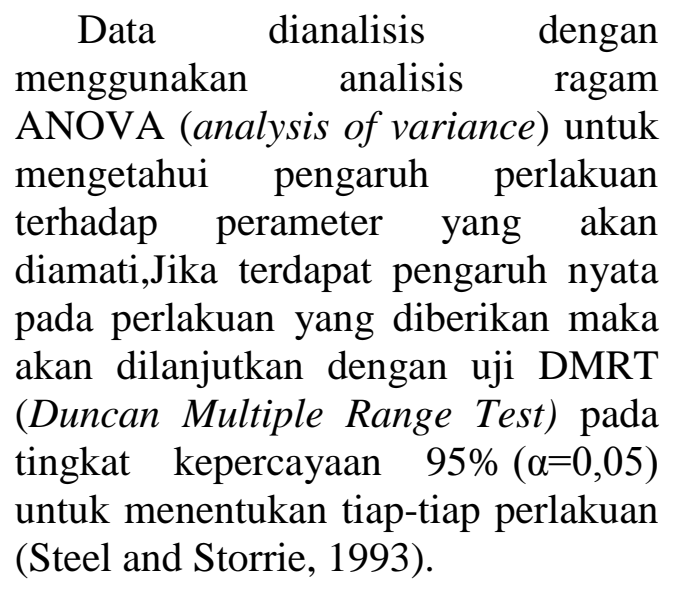

\section{HASIL DAN PEMBAHASAN}

\section{Uji Fitokimia}

Analisis fitokimia dilakukan antara lain flavonoid, alkaloid, saponin, triterpenoid/ steroid. Hasil analisis fitokimia secara kualitatif menunjukan bahwa bulir cendol $K$. alvarezii dan tepung sagu (Metroxylon sagus Rottb) ditemukan flavonoid, alkaloid, steroid namun tidak ditemukan saponin. 
Tabel 1. Hasil Analisis senyawa fitokimia pada bulir cendol K.alvarezii

\begin{tabular}{|c|c|c|c|c|}
\hline No. & Metabolit sekunder & Metode uji & Hasil uji & Indikator \\
\hline 1 & Flavonoid & $\begin{array}{l}\text { Pereaksi HCL } \\
\text { pekat }+\mathrm{Mg}\end{array}$ & $(+)$ & $\begin{array}{l}\text { endapan berwarna } \\
\text { merah }\end{array}$ \\
\hline 2 & Alkaloid & $\begin{array}{l}\text { Pereaksi } \\
\text { Dragendorff }\end{array}$ & $(+)$ & terdapat buih - buih \\
\hline 3 & Saponin & Pereaksi HCL & $(-)$ & $\begin{array}{l}\text { terdapat buih warna } \\
\text { jingga }\end{array}$ \\
\hline 4 & Triterpenoid/steroid & Pereaksi LB & $(+)$ & $\begin{array}{l}\text { berubah menjadi } \\
\text { merah,cokelat,berwarna } \\
\text { biru,ungu }\end{array}$ \\
\hline
\end{tabular}

Keterangan : (+) =Ada; $(-)=$ tidak ada

Berdasarkan hasil uji secara kualitatif pada bulir cendol rumput laut $K$. alvarezii dan tepung sagu (Metroxylon sp.) menunjukan adanya senyawa flavonoid, alkaloid, triterpenoid/ streroid sedangkan untuk saponin tidak ditemukan pada bulir cendol. Kandungan fitokimia yang diperoleh dari penelitian ini juga dipengaruhi oleh jenis rumput laut dimana kandungan fitokimia pada setiap jenis rumput laut berbeda. Penelitian yang telah dilakukan oleh Maharany et al., (2017) rumput laut jenis Padina australis lebih banyak mengandung senayawa fitokimia (positif flavonoid, fenol hidrokuinon, triterpenoid, tanin dan saponin) dibandingkan dengan $K$. alvarezii (positif flavonoid, fenol hidrokuinon dan triterpenoid).

\section{Uji Aktivitas Antioksidan}

Antioksidan pada bulir cendol $K$. alvarezii dengan metode DPPH $(1,1$ diphenyl-2-picrylhydrazil) pada perlakuan R1S1, R2S2, R3S3 dan kontrol maka didapatkan hasil aktivitas antioksidan sebagai berikut:

Tabel 2. Hasil nilai $\mathrm{IC}_{50}$ cendol

\begin{tabular}{ccc}
\hline No. & \multicolumn{1}{c}{ Sampel } & Nilai $\mathrm{IC}_{50}(\mu \mathrm{g} / \mathrm{ml})$ \\
\hline 1. & Kontrol $(\mathrm{RL}=0 \% \mathrm{~S}=100 \%)$ & 9425 \\
2. & $\mathrm{R} 1 \mathrm{~S} 1(\mathrm{R} 1=10 \% \mathrm{~S} 1=90 \%)$ & 652 \\
3. & $\mathrm{R} 2 \mathrm{~S} 2(\mathrm{R} 2=20 \% \mathrm{~S} 2=80 \%)$ & 1711 \\
4. & R3S3 $(\mathrm{R} 3=30 \% \mathrm{~S} 3=70 \%)$ & 3261
\end{tabular}

Berdasarkan hasil penelitian
aktivitas antioksidan IC yang
didapat dari penelitian ini tergolong
lemah, diduga diperoleh karena proses
pemanasan dan penambahan jumlah
rumput laut dalam jumlah yang
sedikit. Menurut Suresh et al., (2007)
rumput laut diketahui memiliki
kandungan senyawa fenolik. Senyawa
fenolik merupakan salah satu
kandungan rumput laut yang berperan

Berdasarkan hasil penelitian aktivitas antioksidan $\mathrm{IC}_{50}$ yang didapat dari penelitian ini tergolong lemah, diduga diperoleh karena proses pemanasan dan penambahan jumlah rumput laut dalam jumlah yang sedikit. Menurut Suresh et al., (2007) kandungan senyawa fenolik. Senyawa kandungan rumput laut yang berperan sebagai antioksidan ekstraksi pada suhu diatas $60^{\circ} \mathrm{C}$ dapat menurunkan senyawa fenolik pada $K$. alvarezii (Sari et al., 2013) ketidakstabilan fenolik pada suhu tinggi tersebut diperkirakan dapat menyebabkan aktivitas antioksidan melemah (Liazid et al., 2007). Perbedaan nilai $1 \mathrm{C}_{50}$ dapat disebabkab oleh jumlah antioksidan yang terkandung dalam ekstrak. Pada variasi waktu 60 menit 
dan 75 menit terjadi penurunan nilai $1 \mathrm{C}_{50}$. Hal ini terjadi akibat kerusakan antioksidan didalam ekstrak yang dipengaruhi oleh lamanya waktu kontak antara zat aktif dengan pelarut yang suhunya semakin meningkat akibat pemanasan yang lama (Dewi et al., 2016).Penambahan sagu pada bulir cendol memperlihatkan kemampuan $\mathrm{IC}_{50}$ yang semakin baik. Hal ini diduga dengan adanya penambahan tepung sagu maka meningkatkan kandungan $\mathrm{IC}_{50}$ bulir cendol. Perubahan signifikan pada nilai $\mathrm{IC}_{50}$ pada cendol tepung sagu sebagai kontrol disetiap perlakuan dipengaruhi oleh perubahan suhu gelatinisasi yang dipengaruhi oleh beberapa faktor, yakni banyaknya senyawa hidrofil yang mengikat air, rasio amilosa: amilopektin, dan kualitas protein. Menurut Shujun et al., (2006) pati berkaitan dengan proporsi gugus hidroksil dalam bentuk ikatan hidrogen dan ikatan kovalen antar molekul pati sedangkan pada proses pengolahan sagu menjadi pati sagu, diduga terjadi penurunan hasil dan kualitas serta nilai fungsional dari pati sagu. Penelitian lain melaporkan bahwa adanya korelasi linear atau hubungan yang sangat positif diperoleh antara nilai tepung komposit berkontribusi secara signifikan pada aktivitas antioksidanya. Tepung komposit diproduksi menggunakan campuran tepung pisang dan jagung dengan perbandingan (100:0, 90:10, 80:20, $70: 30,60: 40,50: 50,40: 60,30: 70$, 20:80, 10:90, 0:100). Kapasitas total antioksidan menunjukan bahwa formula tepung komposit F7,F8,F9,F10 mempunyai kapasitas paling tinggi sedangkan $\mathrm{F} 1$ menunjukan paling rendah potensi antioksidanya. Hasil ini mengindikasikan bahwa penambahan tepung jagung pada semua konsentrasi memiliki efek sinergis untuk meningkatkan kapasitas total antioksidan dalam tepung komposit. Penelitian ini juga memperlihatkan bahwa kapasitas total antioksidan dengan uji fosfomobdat dapat diperbandingkan dengan kandungan fenolik yang terdapat dalam tepung komposit (Edi et al., 2017).

\section{KESIMPULAN}

Berdasarkan hasil penelitian, maka dapat disimpulkan bahwa kandungan fitokimia pada cendol rumput laut berupa senyawa flavonoid, alkaloid, triterpenoid dan steroid terdeteksi, sedangkan negatif pada senyawa saponin. Sedangkan pada uji aktivitas antioksidan menggunakan metode DPPH Terdapat aktivitas antioksidan bulir cendol rumput laut $K$. alvarezii dan tepung sagu (Metroxylon sp.) dengan nilai sampel R1S1 Sebesar $652 \mathrm{mg} / \mathrm{mL}$, R2S2 sebesar $1711 \mathrm{mg} / \mathrm{mL}$ dan pada sampel R3S3 sebesar $3261 \mathrm{mg} / \mathrm{mL}$ dan tergolong antioksidan lemah.

\section{DAFTAR PUSTAKA}

Anggraeni D. 2002. Mempelajari Daya Simpan Cendol pada Penyimpanan Suhu Kamar dan Suhu Refrigerator. [skripsi]. Bogor. Fakultas Teknologi Pertanian. IPB.

Arabei IY. 2000. Vegetable from the sea. Http:/www.Alkalize for Health, net.Library.html.

Ari AC. 2008. Kajian pembuatan cendol dari beberapa bentuk sediaan bahan rumput laut Eucheuma cottonii. Program studi Teknologi Hasil 
Perikanan. fakultas Perikanan dan Ilmu Kelautan. Insitut Pertanian Bogor.

Tristantini D, Ismawati A, Pradana BT, Jonathan JG. 2016. Pengujian Aktivitas Antioksidan Menggunakan Metode DPPH pada Daun Tanjung (Mimusops elengi L). Program Studi Teknologi Bioproses. Universitas Indonesia.

Dotulong V. 2014. Aktivitas Antioksidan Alga Laut Caulerpa sertlaroides, Laurencia tronoi, Padina australis, Isolasi dan Elusidasi Senyawa Aktif Pada Fraksi nHeksana Laurencia tronoi. Disertasi Program Stui Ilmu Pertanian Minat Teknologi Hasil Perikanan. Program Pascasarjana Universitas Brawijaya. Malang

Doty 1987. The production and Uses of Eucheuma. Didalam: Doty MS, Caddy JF, Santelices B (editors). Studies of Seven Commercial

SeaweedsResources. FAO Fish. Tech. Paper No. 281 Rome. P 123-161

Edi S, Lidya IM. 2017. Korelasi antara kapasitas antioksidan dan kandungan fenolik dari tepung komposit pisang jagung. Program studi kimia. fakultas Matematikan dan Ilmu Pengetahuan Alam, Universitas Samratulangi Manado. Sulawesi Utara.

Kardono LB. 2004. Prospecting On Marine Natural Products for Potensial Functional Foods and Bioactive Substance. Makalah disampaikan Dan pada
Forum Bioteknologi Kelautan dan Perikanan, Badan Riset Kelautan Perikanan.

Departemen Kelautan dan Perikanan, 25 Maret 2004. $15 \mathrm{pp}$.

[KKP] Kementrian Kelautan dan Perikanan, 2011. Kelautan dan Perikanan dalam Angka 2011.. Jakarta.

Koswara S. 2009. Teknologi Modifikasi Pati. Ebook Pangan.com.

Liazid A, Palma M, Brigui J, Barroso CG. 2007, Investigation on phenolic compounds stability during microwave-assisted extraction.

Journal Chromatography A. 11(40): 29-34.

Maharany F, Nurjanah, Suwardi R, Anwar E, Hidayat T. 2017. Kandungan Senyawa Bioaktif Sebagai Bahan Baku Krim tabir Surya. JPHPI. 20 (1).

Muhidin, Sitti L, Makmur JA, Sumarlim. 2012. Pengaruh Perbedaan Karakteristik Iklim Terhadap Produksi Sagu. Jurusan Agroteknologi. FAPERTA. Universitas Haluoleo. Kendari

Mulyo BW. 2016. Kajian Pengolahan Pati Sagu (Metroxylon Sago R.) terhadap Daya Cerna Pati, Kadar Pati dan Kadar Air pada Olahanya. Semarang. Jawa Tengah

Nursanto I. 2004. Pembuatan Minuman Sebagai Usaha Diversifikasi Rumput Laut Eucheuma cottoni. Skripsi Fakultas Perikanan dan Ilmu 
Kelautan Institut Pertanian Bogor. Bogor: IPB.

Salazar-Alanda R,Perez-Lopes L, Joel L, Noemi W. 2009. Antimicrobial and antioxidant activities of plants from Northeast of Mexico. Sucursal tecnol ogico. 1:1-6

Siriwardhana N, Lee KW. and Kim, S.H. 2003. Antioxidant activity of hizikia fusiformis on reactive oxygen species scavenging and lipid peroxidation inhibition. Food Sci. \& Technol. Int. 5: 339-34. 